\title{
Kondisi Bawah Permukaan di Sekitar Tebing Watukosek
}

\author{
Alif P. Arwananda, Wien Lestari, dan Juan P.G.N. Rochman \\ Jurusan Teknik Geofisika, Fakultas Teknik Sipil dan Perencanaan, Institut Teknologi Sepuluh Nopember (ITS) \\ Jl. Arief Rahman Hakim, Surabaya 60111 Indonesia \\ e-mail: Wien.geofisika@gmail.com, Juanpandu@geofisika.its.ac.id
}

\begin{abstract}
Abstrak-Salah satu penyebab munculnya semburan lumpur Sidoarjo yang masih diperdebatkan hingga saat ini yaitu mengenai reaktivasi patahan watukosek. Studi yang telah dilakukan sebelumnya menunjukkan adanya manifestasi di permukaan akibat patahan watukosek, contohnya Tebing Watukosek dan pembelokan geomorfologi Kali Porong. Penelitian dengan menggunakan metode tahanan jenis dilakukan untuk memetakan patahan yang berada di daerah Kali Porong dan Patahan Watukosek. Lintasan yang digunakan memiliki bentangan 400m dengan arah Barat - Timur untuk memotong patahan yang berarah Barat Daya - Timur Laut dari Gunung Penanggungan menuju semburan lumpur Sidoarjo. Kedalaman pengukuran mencapai $\mathbf{7 4 . 8 m}$ dengan anomali tahanan jenis terendah 1.05 Ohm.m hingga yang tertinggi 33.3 Ohm.m.
\end{abstract}

Kata Kunci-Patahan Watukosek; Tebing Watukosek; Lumpur Sidoarjo; Metode Tahanan Jenis 2-D.

\section{PENDAHULUAN}

$\mathrm{P}$ ATAHAN watukosek merupakan salah satu penyebab terjadinya fenomena lumpur Sidoarjo yang masih diperdebatkan keberadaannya. Salah satu asumsi hubungan antara patahan watukosek dengan lumpur Sidoarjo, yaitu adanya reaktivasi patahan watukosek yang disebabkan oleh gempa Yogyakarta pada tanggal 27 Mei 2006 dengan jarak epicenter $\pm 250 \mathrm{~km}$ dari pusat semburan lumpur [1]-[3].

Bukti penguat adanya patahan watukosek menurut Mazzini [1] dan Abidin [4] yaitu, adanya pembelokan pada jalur Kali Porong, bentuk Tebing Watukosek (Watukosek Escarpment) sebagai manifestasi dipermukaan, dan orientasi arah patahan pada area pusat semburan. Patahan watukosek diduga dimulai dari Gunung Penanggungan dan memiliki arah Barat Daya Timur Laut yang melewati pusat semburan lumpur Sidoarjo.

Penelitian lebih lanjut dilakukan untuk menelusuri kondisi bawah permukaan pada area yang diduga melintasi Tebing Watukosek dan mempengaruhi bentuk geomorfologi Kali Porong dengan menggunakan metode tahanan jenis 2-D.

Kelebihan metode tahanan jenis dibandingkan metode geofisika lainnya yaitu, tidak merusak kondisi permukaan, tingkat penetrasi arus listrik yang konsisten sesuai konfigurasinya, memiliki banyak konfigurasi untuk disesuaikan dengan targetnya [5], dan memiliki respons yang tinggi terhadap perubahan resistivitas antar lapisan [6]. Metode ini juga digunakan karena efek dari patahan pada suatu batuan dapat terisi oleh lapisan ataupun fluida, sehingga arus listrik yang mengalir dapat mendeteksi perbedaan antara lapisan batuan dengan lapisan untuk mengisi ruang dipatahan ataupun dengan fluida.

Penggunaan metode tahanan jenis memiliki parameter kontrol dibandingkan metode geofisika lainnya, yaitu kedalaman penetrasi arus listrik dan nilai tengangan yang terukur/resolusi data [7]. Kedua parameter tersebut dibatasi oleh konfigurasi yang digunakan dalam akuisisi data, sehingga penggunaan konfigurasi juga menentukan target objek yang akan dicari [8]. Sehubungan dengan topik penelitian yang ditentukan, yaitu untuk menentukan kondisi bawah permukaan maka konfigurasi yang digunakan haruslah memiliki penetrasi yang dalam.

\section{URAIAN PENELITIAN}

\section{A. Fisiografi Regional}

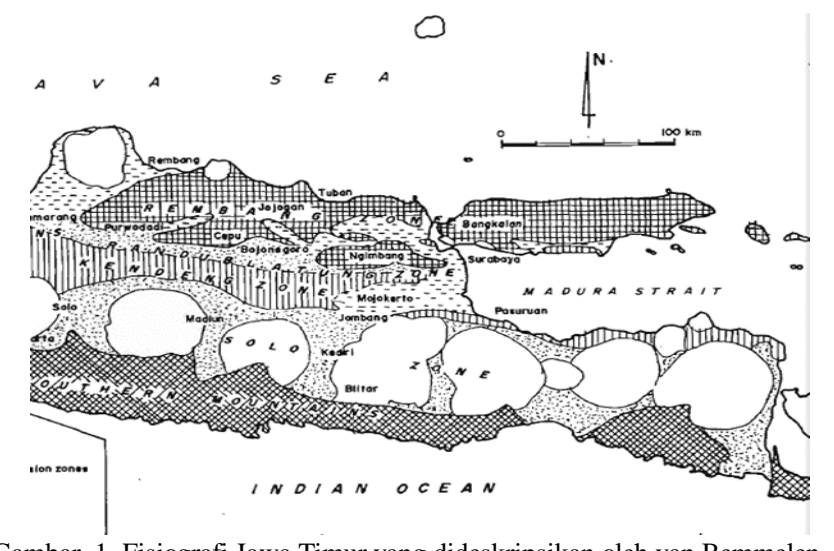

Gambar. 1. Fisiografi Jawa Timur yang dideskripsikan oleh van Bemmelen.

Van Bemmelen [9] mengelompokkan Jawa Timur menjadi empat zona, yaitu zona Rembang, zona Kendeng, zona Solo, dan zona Pegunungan Selatan. Area penelitian yang berada di daerah Sidoarjo berada di zona Kendeng. Zona Kendeng memiliki kemiripan seperti zona Rembang, zona yang terdiri dari endapan laut dangkal, sedimen klastik, dan batuan karbonat [10]. Zona Kendeng juga merupakan antiklinorium yang memanjang mulai dari Barat hingga Timur [11], dengan penyusun volkanogenik dan sedimen plagik. 


\section{B. Metode Tahanan Jenis}

Pengambilan data dengan metode geofisika tahanan jenis memanfaatkan sifat tahanan jenis yang dimiliki oleh mineral atau fluida yang terkandung dalam suatu batuan atau lapisan. Pengambilan data tahanan jenis dimulai dengan mengalirkan arus listrik langsung (DC) ke bawah permukaan dalam suatu ruang berbentuk setengah bola. Prinsip dasar metode ini adalah mengarlikan arus listrik searah atau bolak-balik dengan frekuensi rendah kedalam bumi [12]. Hasil pengukuran tahanan jenis merupakan nilai tahanan jenis "semu", dimana nilai tahanan jenis tersebut memiliki asumsi bahwa kondisi dibawah permukaan bersifat homogen, sehingga akan memberikan nilai tahanan jenis yang sama, dengan syarat konfigurasi elektroda yang digunakan juga sama.

Menurut Loke [13] ada empat hal yang harus dipertimbangkan dalam menentukan konfigurasi elektroda yang digunakan, yaitu sensitivitas perubahan tahanan jenis secara vertikal dan horizontal, target kedalaman, cakupan data pengukuran horizontal, dan terakhir yaitu kekuatan sinyal.

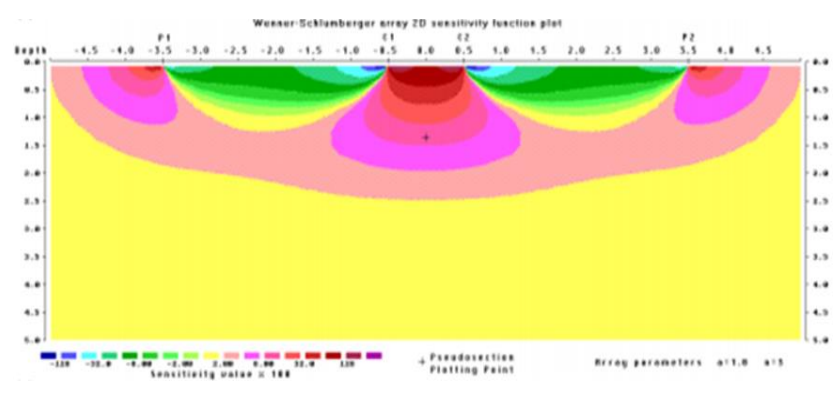

Gambar. 2. Penampang sensitivitas dengan menggunakan konfigurasi Wenner-Schlumberger. (Loke, 1999)

Berdasarkan prinsip dasar tahanan jenis yang menggunakan Hukum Ohm, persamaan untuk hambatan jenis yaitu:

$$
\mathrm{R}=\frac{\mathrm{v}}{\mathrm{I}}
$$

Dengan V melambangkan tegangan, I melambangkan arus, dan R melambangkan hambatan. Hanya saja, yang diukur kali ini adalah tahanan jenis sehingga nilai yang diukur harus diganti menjadi tahanan jenis semu menjadi:

$$
\mathrm{P}=\frac{V}{I}
$$

Karena pengukuran potensial dilakukan dengan 2 (dua) buah elektroda potensial sehingga besar [14] tegangan yang terukur menjadi:

$$
\rho_{a}=K \frac{\Delta V}{I}
$$

\section{Metode Inversi Least Square}

Inti dari metode least-square ini yaitu memberikan model dengan nilai perhitungan atau error terkecil, memiliki persamaan:

$$
m=\left(A^{T} A\right)^{-1} A^{T} d
$$

Metode inversi ditujukan untuk merekonstruksi model dari data observasi/pengukuran, atau bagaimana merubah data untuk menghasilkan suatu model. Inversi dapat digunakan untuk mengestimasi kualitas dari parameter model yang akan didapat, jenis parameter model yang akan didapat, jenis parameter model, atau data yang paling baik dalam pembuatan model (tanpa gangguan/noise)

Selain meminimalisir perbedaan antara nilai tahanan jenis, metode inversi juga mengurangi parameter lainnya sehingga model yang dihasilkan sesuai dengan kondisi sesungguhnya. Untuk menemukan model yang sesuai dengan kondisi geologi yang ada, secara default RES2DINV menggunakan proses inversi smoothnes-constrained [15] yang memiliki persamaan:

$$
\left(J^{n_{T}} J+\mu F\right) d=J^{n_{T}} g-\mu F r
$$

Dimana, F melambangkan matrix untuk smoothing, J melambangkan matrix Jacobian, $r$ melambangkan vector logaritma dari model nilai tahanan jenis, $\mu$ melambangkan faktor peredaman (damping), d melambangkan vector gangguan, dan g melambangkan vector perbedaan.

\section{METODOLOGI PENELITIAN}

\section{A. Metodologi Penelitian}

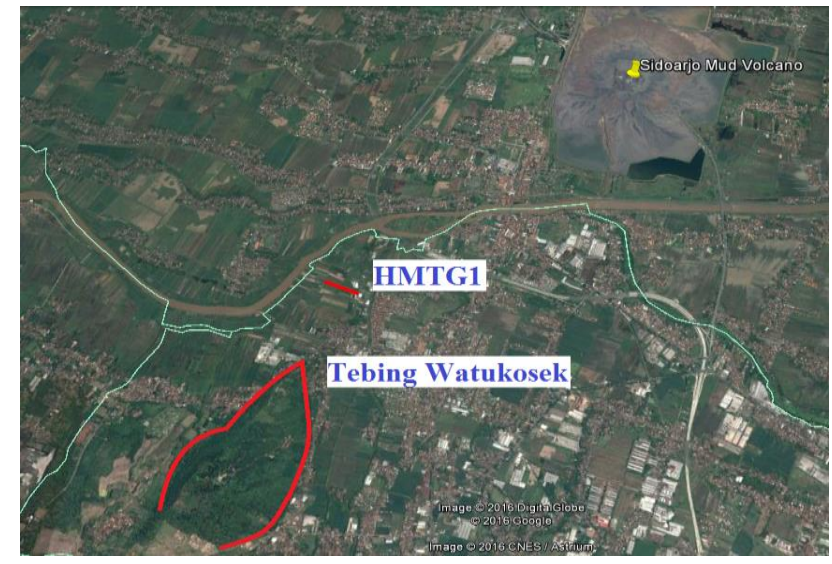

Gambar. 3. Desain lintasan pengukuran HMTG1.

Lokasi penelitian berada di daerah Selatan semburan gunung lumpur yang ditandai dengan garis merah (Gambar. 3). Lintasan memanjang dari Barat menuju Timur. Lintasan berarah Barat - Timur ditujukan untuk memotong patahan watukosek yang diduga berarah Barat Daya - Timur Laut.

Setelah pengukuran dilakukan di 2 lintasan, proses inversi dilakukan dengan menggunakan parameter inversi sebagai berikut:

Tabel 1.

Parameter inversi yang digunakan selama proses pengolahan data

\begin{tabular}{lc}
\hline \multicolumn{1}{c}{ Parameter Inversi } & Nilai \\
\hline Use model refinement & Cells with width of half the \\
& unit spacing \\
Optimise damping factor & Yes \\
Vertical/Horizontal flatness ratio & 1.0 \\
Include smoothing & Yes \\
Percentage change for line search & $0.1 \%$ \\
Number of iteration & 20 \\
Type of mesh for forward modelling & Finest mesh; 4 nodes \\
\hline \hline
\end{tabular}




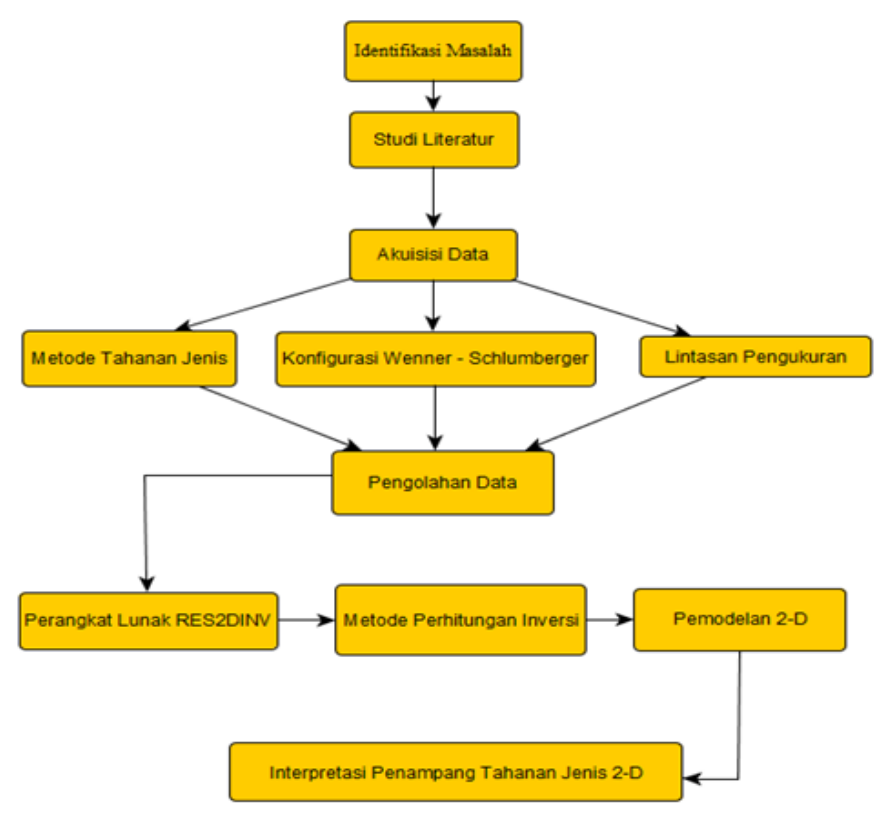

Gambar. 4. Diagram alir pengerjaan penelitian.

\section{HASIL DAN PEMBAHASAN}

\section{A. Analisis Patahan}

Dari hasil inversi data pengukuran didapat penampang dengan kedalaman $\pm 74.8 \mathrm{~m}$ error $2.1 \%$ untuk lintasan HMTG1.

Penampang HMTG1 tidak memiliki anomali patahan walaupun lintasan pengukuran dekat dengan Tebing Watukosek dan Kali Porong yang memotong arah dugaan patahan watukosek. Lintasan HMTG1 memiliki nilai tahanan jenis tinggi pada jarak $160 \mathrm{~m}-220 \mathrm{~m}$ dengan nilai \pm 33.3 Ohm.m, hal ini diduga merupakan nilai tahanan jenis dari jembatan yang ada pada lintasan pengukuran. Lintasan HMTG1 tidak memiliki anomali patahan watukosek hingga kedalaman $\pm 74.8 \mathrm{~m}$.

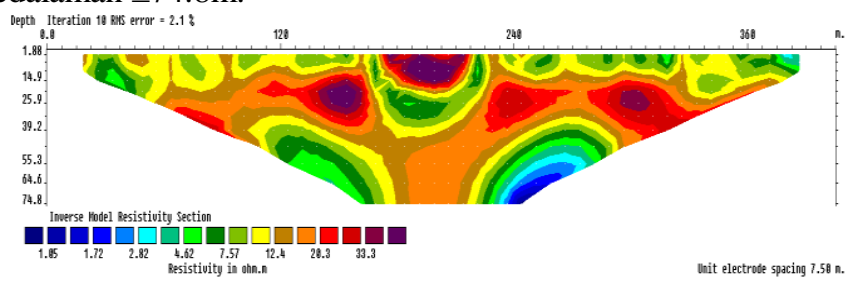

Gambar. 5. Penampang lintasan HMTG1

\section{KESIMPULAN}

Pengukuran yang dilakukan di Utara Tebing Watukosek dan Kali Porong tidak mendapatkan anomali patahan hingga kedalaman \pm 2.54 untuk HMTG1. Hal ini ditunjukkan oleh penampang tahanan jenis 2-D yang tidak menunjukkan anomali tahanan jenis rendah ataupun yang memotong antar lapisan batuan.

\section{DAFTAR PUSTAKA}

[1] A. Mazzini, A. Nermoen, M. Krotkiewski, Y. Podladchikov, S. Planke, dan H. Svensen, "Strike-slip faulting as a trigger mechanism for overpressure release through piercement structures. Implications for the Lusi mud volcano, Indonesia," Mar. Pet. Geol., vol. 26, no. 9, hal. 17511765, Nov 2009.

[2] A. Mazzini et al., "Triggering and dynamic evolution of the LUSI mud volcano, Indonesia," Earth Planet. Sci. Lett., vol. 261, no. 3-4, hal. 375388, Sep 2007.

[3] B. P. Istadi, A. Kadar, dan N. Sawolo, "Analysis \& Recent Study Results on East Java Mud Volcano," dipresentasikan pada Subsurface sediment remobilization and fluid flow in sedimentary basins, 2008, hal. 53-55.

[4] H. Z. Abidin, R. J. Davies, M. A. Kusuma, H. Andreas, dan T. Deguchi, "Erratum to: Subsidence and uplift of Sidoarjo (East Java) due to the eruption of the Lusi mud volcano (2006-present)," Environ. Geol., vol. 57, no. 4, hal. 845-846, Apr 2009.

[5] R. Herman, "An introduction to electrical resistivity in geophysics," Am. J. Phys., vol. 69, no. 9, hal. 943, 2001.

[6] Sehah dan Sugito, "Pencitraan Resistivitas 2D Bawah Permukaan Tanaman Jati (Tectona Grandis Sp.) Menggunakan Konfigurasi Wenner (Studi Kasus: Lahan Tanaman Jati di Belakang Gedung MIPA UNSOED)," Berk. Fis., vol. 14, no. 1, hal. 1-10, 2012.

[7] J. Bernard, "Short Note on The Depth of Investigation of Electrical Methods.pdf," Heritage Geophysics Inc, Jul-2003. [Daring]. Tersedia pada: http://www.heritagegeophysics.com/papers/Depth_of_investigation.pdf.

[8] A. K. Abdul-Nafiu, M. N. M. Nordin, K. Abdullah, I. K. Saheed, dan A. Abdullah, "Effects of Electrode Spacing and Inversion Techniques on the Efficacy of 2D Resistivity Imaging to Delineate Subsurface Features," Am. J. Appl. Sci., vol. 10, no. 1, hal. 64-72, Jan 2013.

[9] R. W. van Bemmelen, The Geology of Indonesia, vol. Vol. 1A. The Hague: Government Printing Office, 1949.

[10] J. P. Buranda, Geologi Indonesia: bahasan: teori undase / oleh J. P. Buranda. Malang: Universitas Negeri Malang, 1999.

[11] Susilohadi, "Later Tertiary and Quaternary Geology of the East Java Basin, Indonesia," Doctor of Philosophy Thesis, University of Wolonggong, New South Wales, Australia, 1995.

[12] A. Kuswanto, "Pengembangan Metode Geolistrik 4-D untuk Perembesan Bawah Tanah Development of 4-D Geoelectric Methode to Identify Subsurface Leakage," Pros. Pertem. Ilm. Nas BPPT, hal. 182-194, Nov 2015.

[13] M. H. Loke, "Electrical imaging surveys for environmental and engineering studies," Pract. Guide To, vol. 2, 1999.

[14] F. Putri, A. Yulianto, dan others, "Monitoring Rembesan Embung Universitas Negeri Semarang Dengan Metode Resistivity," Unnes Phys. J., vol. 2, no. 2, 2013.

[15] de G.-H. Constable, "Occam's inversion to generate smooth, twodimensional models from magnetotelluric data," Geophysics, vol. 55, hal. $1613,1990$. 